\title{
Phenotyping of F2 Segregating Population Derived from Mahamaya X IRBB65 against Bacterial Blight Pathogen (Xanthomonas oryzae pv. oryzae)
}

\author{
Mekala Mallikarjun* and Anil S. Kotasthane \\ Department of Plant Pathology, College of Agriculture, Indira Gandhi Krishi \\ Vishwavidyalaya (IGKV), Raipur - 492012, Chhattisgarh, India \\ *Corresponding author
}

\section{A B S T R A C T}

\section{Keywords}

Rice, Bacterial blight, Resistant genes, Durable resistance

Article Info

Accepted:

26 January 2018

Available Online:

10 February 2018
Bacterial blight (BB) is a major disease of rice for which host resistance is the only effective solution. Pyramiding entails stacking multiple genes leading to the simultaneous expression of more than one gene in a variety to develop durable resistance Expression. Gene pyramiding is gaining considerable importance as it would improve the efficiency of plant breeding leading to the development of genetic stocks and precise development of broad spectrum resistance capabilities. The success of gene pyramiding depends upon several critical factors, including the number of genes to be transferred, the distance between the target genes and flanking markers, the number of genotype selected in each breeding generation, the nature of germplasm etc. The two genes pyramid $\mathrm{Xa} 4+\mathrm{Xa} 7$, $\mathrm{Xa} 7+\mathrm{Xa} 21$ is recently the most utilized combination for developing resistant varieties through marker-assisted breeding. Our study was carried out to elicit the detailed response of forty lines possessing these two genes in genetic of Mahamaya background to isolate of Chhattisgarh. The overall results confirmed that genetic background plays crucial role for the effective expression of $\mathrm{Xa} 4+\mathrm{Xa} 7, \mathrm{Xa} 7+\mathrm{Xa} 21$ combination.

\section{Introduction}

Bacterial blight (BB), caused by Xanthomonas oryzae pv. oryzae (Xoo), is a devastating disease of rice especially in tropical regions (Gautam et al., 2015). Yield losses due to this disease generally vary from $20 \%$ to $30 \%$, but may go up to $50 \%$ depending on the environmental conditions, season, the level of $\mathrm{N}$ application and crop stage (Ou 1985). Although different strategies are followed, the control of bacterial blight disease is difficult due to complex and dynamic nature of the pathogen. Genetic resistance is the only effective, economical and eco-friendly approach for $\mathrm{BB}$ management. In recent decades, host plant resistance has played a significant role in the successful management of this disease. More than 38 resistance genes (Xa/Xa) effective against this disease have been reported globally (Cheema et al., 2008). However, the effectiveness of resistance gene(s) varies with the prevailing climatic conditions, nature of resistance gene and local pathogen population structure (Laha et al., 2009). Pyramiding of different resistance genes in popular cultivars has been found rewarding approach for the effective 
management of disease instead of single-gene incorporation. In India, many BB-resistant varieties have been successfully developed for the sustainable management of rice bacterial blight disease using marker-assisted breeding (Dokku et al., 2013, Pandey et al., 2013).

We hypothesize that the selection of suitable genetic background for resistance gene introgression is one of the prime factors for formulating an effective $\mathrm{BB}$ resistance programme. This consideration is important to ensure justification and appropriation of costs involved in introgressing resistance genes in popular cultivars through conventional as well as marker-assisted breeding and for the durability and wide coverage of genetic resistance. Usually, the susceptible local popular rice cultivars with high yield potential and local consumer preferences are selected for resistance gene(s) transfer. Understanding the nature of the pathogen, its population and genetic diversity are very important to formulate suitable disease management strategies.

DNA fingerprinting method based on repetitive element IS1112 with a very high copy number (around 80 copies in some strains) is widely used to determine the genetic variability among Xoo isolates (Leach et al., 1990) and is commonly followed till date (Lore et al., 2011) Also, the durability of resistance used in breeding programme depends on the speed of evolution of new races of pathogen over space and time as reported by different researchers (Lore et al., 2011)

In the process of resistance gene(s) transfer, it may be important to select the target genetic backgrounds which facilitate the desirable and durable resistance expression this study was carried out for the first time to know the performance of combination of three $\mathrm{BB}$ resistance genes $(\mathrm{Xa} 4+\mathrm{Xa} 7)(\mathrm{Xa} 7+\mathrm{Xa} 21)$ in different genetic background of Mahamaya rice variety in response to Dhamtari isolate of Chhattisgarh.

\section{Materials and Methods}

Experimental materials consisted of $\mathrm{F}_{2}$ lines derived from the cross between Mahamaya $X$ IRBB65. IRBB65 (a near isogenic line in the background of IR24) carrying 4 BLB resistant genes $\mathrm{Xa} 4 \mathrm{Xa7}, \mathrm{xal3}$ and $\mathrm{Xa21}$ which served as donor for this cross and Mahamaya was the recipient parent. $F_{2}$ lines derived from the cross between Mahamaya X IRBB65 were used as the segregating breeding population for the marker assisted selection.

The isolate of Xanthomonas oryzae pv. oryzae (Xoo) collected from Dhamtari was used for evaluation and genetic analysis of $\mathrm{F}_{2}$ segregating population and two parents. The isolate was derived from the stock maintained at $4^{\circ} \mathrm{c}$. Culture was revived and grown on Walkimoto's medium for 3 days at $30^{\circ} \mathrm{C}$. The composition of Walkimoto's medium is given in Table 1. For inoculating the plants bacterial suspension was prepared by mixing bacterial culture in sterilized distilled water to a concentration of $10^{9}$ cells $/ \mathrm{ml}$. This suspension was immediately used for inoculations.

The experimental plant material was inoculated at maximum tillering stage following clip inoculation technique (Kauffman1973) early in the morning or in the evening on a dry cool day. For each line, on an average of 25 leaves per 5 plants were inoculated.

\section{Results and Discussion}

\section{Phenotyping studies}

Individual plants of 61 lines of Mahamaya $\mathrm{X}$ IRBB65 derived $\mathrm{F}_{2}$ breeding segregating population and two parents were evaluated for 
field infections to bacterial blight. Observations were recorded by physical measurement of lesion and percent leaf area was worked out. Scoring for the disease incidence was evaluated 21 days after inoculation.

The lesion length and total leaf length was recorded on five leaves and were further categorized based on 0-9 scale. (IRRI, 1991) which is as follows: $0=$ No lesion length, $1=$ lesion restricted to 0.5 to $1.0 \mathrm{~mm}, 3=$ lesion elongated but less than $1 / 4$ of leaf blade, $5=$ lesion extended to $1 / 2$ of the leaf blade, $7=$ lesion extended to more than $1 / 2$ of the leaf blade, $9=$ lesion completely destroyed the leaf blade and sheath. The disease score were rated as HR, R, MR, S, and HS (Table 1).

Analysis of virulence / avirulence response of Xanthomonas oryzae pv. oryzae isolates from Dhamtari

Avirulence genes are originally defined by their negative impact on the ability of a pathogen to infect their host plant. Many avirulence genes are now known to represent a subset of virulence factors involved in the mediation of the host pathogen interaction. Characterization of avirulence genes has revealed that they encode an amazing assortment of proteins and belong to several gene families. Avirulence genes are defined by corresponding resistance (R) genes of which a relatively large number have now been cloned. The resistance response is typically accompanied by a hypersensitive reaction (HR), which is a form of programmed cell death; burst of superoxide production; and the expression of defense genes. The direct interaction of the R protein and AVR ligand results in activation of the plant defense response, which often involves a hypersensitive response (HR). Race specific interactions such as those observed between Xanthomonas oryzae pv. oryzae and rice are thought to follow the gene for gene model, which predicts that incompatible interaction are the consequence of positive functions encoded by avirulence genes in the pathogen and corresponding $\mathrm{R}$ gene in the host.

If the pathogen lacks the appropriate avr gene or the host plants lack the $\mathrm{R}$ gene, a compatible interaction is established. In this case, the pathogen is able to overcome innate host defenses, and cause disease on rice through the use of extracellular enzymes, extracellular polysaccharides and other factors.

The direct interaction of the $\mathrm{R}$ protein and Avr ligand results in activation of the plant defense response, which often involves a hypersensitive response (HR) and therefore monitoring avr gene in the surviving pathogen population can be an indirect strategy for the breeding for disease resistance and deployment of an $\mathrm{R}$ gene. prompted Nevertheless the issue us to speculate the virulence/avirulence gene(s) in Dhamtari xoo isolated to contain avrXa4, avrXa7 avrxal3 and avrxa21 based on its hypersensitive reactions in the lines, containing two $R$ gene(s) in combinations (Table 1).

Improving the resistance to bacterial blight of rice utilizing the broad spectrum genes and development of resistant cultivars is an economic environmental and efficient method. Bacterial populations are notoriously "shifty enemies" and often circumvent disease management strategies. Deployment of rice varieties has been subject to boom and-bust cycles and effective resistance to the bacterial blight pathogen, (Xanthomonas oryzae pv. oryzae), is often short lived, owing to the shift in the pathogen population towards virulent races. The effectiveness of resistance genes varies over locations due to geographical structuring of the pathogen. 
Table.1 Composition of the Walkimoto media

\begin{tabular}{|c|c|c|}
\hline S. NO & Component & Quantity /litre \\
\hline 1 & Peeled potatoes & $300 \mathrm{gm}$ \\
\hline 2 & Sucrose & $20 \mathrm{gm}$ \\
\hline 3 & Peptone (bacteriological grade) & $5 \mathrm{gm}$ \\
\hline 4 & Sodium dihydrogen phosphate & $1.87 \mathrm{gm}$ \\
\hline 5 & Calcium nitrate & $0.5 \mathrm{gm}$ \\
\hline 6 & Agar-Agar (bacteriological grade) & $17 \mathrm{gm}$ \\
\hline 7 & Distilled water & $1000 \mathrm{ml}$ \\
\hline 8 & $\mathrm{pH}$ & 6.8 \\
\hline
\end{tabular}

Table.2

\begin{tabular}{|c|c|c|}
\hline Score & Lesion length & Reaction \\
\hline $\mathbf{0}$ & No lesion length & Highly Resistant (HR) \\
\hline $\mathbf{1}$ & 0.5 to $1.0 \mathrm{~mm}$ & Resistant (R) \\
\hline $\mathbf{3}$ & less than $1 / 4$ of leaf blade & Moderately Resistant (MR) \\
\hline $\mathbf{5}$ & lesion extended to $1 / 2$ of the leaf blade & Moderately Susceptible (MS) \\
\hline 7 & lesion extended to more than $1 / 2$ of the leaf blade & Susceptible (S) \\
\hline 9 & lesion completely destroyed the leaf blade and sheath & Highly Susceptible(HS) \\
\hline
\end{tabular}

Table.3

\begin{tabular}{|l|l|}
\hline Introgressed line(s) with two gene(s) $X a 7+X a 21$ & Line \# 5,13,27,36,39 \\
\hline Introgressed line(s) with two gene(s) $X a 4+X a 7$ & Line \# 2
\end{tabular}

Knowledge of the pathogen population structure and virulence characteristics is therefore essential for a successful breeding program aimed at durable resistance.

Long-term cultivation of rice varieties carrying single resistance gene has resulted in a significant shift in pathogen-race frequency and consequent breakdown of resistance.

One tangible solution to resistance breakdown is pyramiding of multiple resistance genes in the background of modern high yielding varieties. The probability of simultaneous pathogen mutations for virulence to defeat two or more effective genes is much lower than with a single gene. Gene pyramiding is difficult to achieve using conventional breeding alone because of linkage with some undesirable traits that is very difficult to break even after repeated backcrossing. When two or more genes are introgressed, phenotypic evaluation is unable to distinguish the effect of individual gene precisely since each gene confers resistance to and combats multiple races of the pathogen. In present work resistance lines of a high yielding cultivar are developed through introgression of BLB resistance gene(s) using marker-assisted selection in a backcross-breeding program. Four bacterial blight resistant genes namely $\mathrm{Xa4}, \mathrm{Xa7}, \mathrm{xa} 13$ and $\mathrm{Xa21}$ have been introgressed into Mahamaya. We identified Five $(\# 5,13,27,36,39)$ lines carrying two gene pyramids $(\mathrm{Xa}+\mathrm{Xa21})$. One (\#2) line is also carrying two gene pyramid $(X a 4+X a 7)$. 


\section{Acknowledgments}

This work was supported by the Molecular Plant Pathology Laboratory of Department of Plant Molecular Biology and Biotechnology, CoA, IGKV Raipur. We thank Dr. A.S. Kotasthane and Dr. Toshy Agarwal for their Assistance and Suggestions

\section{References}

Cheema, K., N. Grewal, and Y. Vikal, 2008: A novel bacterial blight resistance gene from Oryza nivara mapped to $38 \mathrm{~kb}$ region on chromosome $4 \mathrm{~L}$ and transferred to Oryza sativa L. Genet. Res. (Camb.) 90, 397-407.

Dokku, P., K. M. Das, and G. J. N. Rao, 2013: pyramiding of four resistance genes of bacterial blight in Tapaswini, an elite rice cultivar, through marker assisted selection. Euphytica 192, 8796.

Gautam, R. K., P. K. Singh, K. Sakthivel, M. Srikumar, N. Kumar, K. Kumar, A. K. Singh, and S. D. Roy, 2015: Analysis of pathogenic diversity of the rice bacterial blight pathogen (Xanthomonas oryzae pv. oryzae) in the Andaman Islands and identification of effective resistance genes. J. Phytopathol. 16, 423-432.

Kauffman, H. E., A. P. K. Reddy, S. P. Y. Hsieh, and S. D. Merca, 1973: An improved technique for evaluating resistance in rice varieties to Xanthomonas oryzae. Plant Dis. Report 57, 537-541
Laha, G. S., C. S. Reddy, D. Krishnaveni, R. M. Sundaram, M. Srinivas Prasad, T. Ram, K. Muralidharan, and B. C. Viraktamath, 2009: Bacterial blight of rice and its management. Technical Bulletin No. 41. Directorate of Rice Research (ICAR), Hyderabad, AP, India, 37.

Leach, J. E., F. F. White, M. L. Rhoads, and H. Leung, 1990: A repetitive DNA sequence differentiates Xanthomonas campestris pv. oryzae from other pathovars of Xanthomonas campestris. Mol. Plant Microbe Interact. 3, 238246.

Lore, J. S., Y. Vikal, M. S. Hunjan, R. K. Goel, T. S. Bharaj, and G. L. Raina, 2011: Genotypic and pathotypic diversity of Xanthomonas oryzae pv. oryzae, the cause of bacterial blight of rice in Punjab state of India. J. Phytopathol. 159, 479-487.

Ou, S. H., 1985: Rice Diseases. Common wealth Mycological Institute, Farham House, UK. p. 380.

Pandey, M. K., R. N. Shobha, R. M. Sundaram, G. S. Laha, M. S. Madhav, R. K. Srinivasa, I. Sudharshan, Y. Hari, G. S. Varaprasad, R. L. V. Subba, K. Suneetha, A. K. P. Sivaranjani, and B. C. Viraktamath, 2013: Improvement of two traditional Basmati rice varieties for bacterial blight resistance and plant stature through morphological and marker- assisted selection. Mol. Breeding 31, 239-246.

\section{How to cite this article:}

Mekala Mallikarjun and Anil S. Kotasthane. 2018. Phenotyping of F2 Segregating Population Derived from Mahamaya X IRBB65 against Bacterial Blight Pathogen (Xanthomonas oryzae pv. oryzae). Int.J.Curr.Microbiol.App.Sci. 7(02): 3276-3280. doi: https://doi.org/10.20546/ijcmas.2018.702.393 